\title{
Price and Income Elasticities of Consumer Goods Imports of Pakistan
}

\author{
KHWAJA SARMAD and RIAZ MAHMOOD*
}

\section{INTRODUCTION}

Estimation of disaggregated import elasticities for developing countries presents a formidable data-handling problem. The available studies on the subject are concerned mostly with the estimation of income and price elasticities of imports at a disaggregated level corresponding to the one-digit level of the Standard International Trade Classification (SITC), see, e.g., Khan [1], Melo and Vogt [4], Nguyen and Bhuyan [5]. Consequently, they apply a common elasticity estimate to all commodity sub-groups.

The lack of disaggregated estimates of import elasticities is a serious constraint on the efforts to quantify the effects of policy measures on the volume of imports and economic welfare in general. In this study an attempt has been made to overcome this limitation by estimating price and income elasticities of the consumer goods imports of Pakistan at the three-digit level of the SITC. Consumer goods imports have also been distinguished by functional classes, viz. consumer goods and raw materials for consumer goods.

In this study the importance of changes in relative prices, customs duties and an income variable as explanatory variables determining the quantity of consumer goods imports of Pakistan, has been investigated for the period from 1969-70 to 1979-80. During this time there was a growing structural concentration of imports in favour of consumer goods, which, by the end of the Seventies, accounted for around 60 percent of the total imports. There is also evidence of concentration between different products of the same industry, which suggests that some benefit can be gained by studying imports on a disaggregative basis, in particular by using information at the three-digit SITC level as the basic data. The fact that this is also the decision level for tariff policy provides additional cause for a disaggregative approach.

The required data on quantity and value of imports were generated by aggregating the six-digit series available in the Foreign Trade Statistics [6]. Prices for

*The authors are, respectively, Senior Research Economist and Staff Economist at the Pakistan Institute of Development Economics (PIDE), Islamabad. They are grateful to Prof. Syed Nawab Haider Naqvi, Director, PIDE, for his constant encouragement in completing this study. They also thank Mr Masood Ashfaque for computing assistance. 
domestic substitutes were obtained from Government of Pakistan publications [8] [9], [10] and [11]. The division of consumer imports into functional classes was made according to the methodology outlined in [3]. The value of the selected commodities in the categories of consumer goods and raw materials for consumer goods accounts for 68 percent and 59 percent respectively of the total imports in these categories. Together they account for 35 percent of the total imports of Pakistan during the period from 1969-70 to 1979-80.

\section{THE IMPORT FUNCTION}

The following import demand function is estimated:

$$
\log M_{i t}^{d}=e_{0 i}+e_{l i} \log \left(1+C D_{i}\right) P_{i m} / P_{d i}+e_{2 i} \log Y_{t}+u_{i t} \ldots
$$

where

$$
\begin{aligned}
& M_{i}^{d}=\text { quantity demanded of the } i \text { th import commodity; } \\
& P_{i m}=\text { price of the } i \text { th import commodity; } \\
& P_{d i}=\text { price of a domestic substitute; } \\
& C D_{i}=\text { custom duty on the } i \text { th commodity; }
\end{aligned}
$$

$Y_{t}=$ real income variable - the proxies used are real consumption expenditure for consumer goods imports, and real value added in the manufacturing sector for imports of raw materials for consumer goods; and

$u_{i} \quad=\quad$ random disturbance term.

The specification of the import function in logarithms allows the import elasticities to be obtained directly from equation (1). The underlying assumptions for estimating the import equations are as follows: (i) importers are always in equilibrium $\left(M_{i}^{d}=M_{i}\right)$; and (ii) real private consumption expenditure, real value added in the manufacturing sector, the price of the imported commodity $P_{i m}$ and that of the domestic substitute are exogenously determined. In general, the adjusted relative price elasticities $\left(e_{l i} s\right)$ are expected to be less than zero and the income elasticities $\left(e_{z i} s\right)$ greater than zero. Negative values for the income elasticity can also be justified, when domestic production increases more than consumption with a rise in the level of income.

\section{RESULTS}

The estimates of the parameters of equation (1) were obtained for variou commodity groups and are reported in Table 1 . The table also reports the t-value in parentheses, the value of $\bar{R}^{2}$, the Durbin-Watson (D.W.) statistic, and the Standard Error (S.E.) of the estimated equation.

For a number of cases, code-numbered 051 (Fresh Fruits), 074 (Tea), 211 (Waste and Used Leather), 231 (Crude Rubber), 422 (Palm Oil), 512 (Acids an Compounds) and 561 (Urea), there was evidence of first-order autocorrelation in the residuals, $u_{t}$

The results in Table 1 show that out of 26 cases the price elasticity estimates are statistically significant at the 95 -percent level for thirteen groups of imports; for three cases the estimates are statistically significant at the 90-percent level; and for another five cases the estimates are statistically significant at the 80 -percent level. For almost half the cases the price elasticities have the expected negative sign. ${ }^{2}$

\section{AGGREGATION BIAS}

To obtain estimates of price and income elasticities for aggregate imports on the basis of disaggregate estimates, Khan [1] has suggested that the estimates be adjusted by the "distribution elasticities" which, if not accounted for, would bias the aggregate estimates. To investigate the aggregation bias we have calculated the price and income elasticities for consumer goods imports at the one-digit level of the SITC directly and on the basis of disaggregated import elasticities.

The distribution elasticities are calculated from the following equation and are reported in Table 2:

$$
\Delta \log P_{i t} \quad=\quad \beta_{i} \Delta \log P_{t}+v_{t} \quad \ldots \quad \ldots \quad \ldots \quad \ldots \ldots
$$

${ }^{1}$ Given that import demand is excess demand, very little can be said in general about the properties of the import demand function other than that it is homogeneous of degree zero in absolute prices. As such there can be no $a$ priori presumptions about the elasticities without additional assumptions.

${ }^{2}$ Kreinin [2] and Price and Thornblade [12] have suggested that a positive price elasticity may be due to the high level of disaggregation. 
Table 1

\begin{tabular}{|c|c|c|c|c|c|c|}
\hline \multicolumn{7}{|c|}{ Estimates of Import Equations } \\
\hline $\begin{array}{l}\text { Commodity } \\
\text { Group }\end{array}$ & $\begin{array}{c}\text { PSTC } \\
\text { Equivalent }\end{array}$ & $\begin{array}{c}\text { Price } \\
\text { Elasticity }\end{array}$ & $\begin{array}{c}\text { Income } \\
\text { Elasticity }\end{array}$ & $\bar{R}^{2}$ & D.w. & S.E. \\
\hline (1) & (2) & (3) & (4) & (5) & (6) & (7) \\
\hline \multicolumn{7}{|l|}{ Consumer Goods } \\
\hline Food Products & 0 & $\begin{array}{l}1.040 \\
(1.824)\end{array}$ & $\begin{array}{l}1.217 \\
(1.319)\end{array}$ & 0.407 & 2.149 & 0.527 \\
\hline Milk and Cream & 022 & $\begin{array}{l}-1.408 \\
(-4.592)\end{array}$ & $\begin{array}{c}4.209 \\
(7.200)\end{array}$ & 0.861 & 1.559 & 0.366 \\
\hline Milk Food for Infants & 099 & $\begin{array}{c}0.031 \\
(0.035)\end{array}$ & $\begin{array}{c}5.852 \\
(5.733)\end{array}$ & 0.756 & 2.572 & 0.647 \\
\hline Milk, Cream and Milk Food & $002+099$ & $\begin{array}{l}-1.351 \\
(-4.354)\end{array}$ & $\begin{array}{l}4.267 \\
(7.929)\end{array}$ & 0.878 & 1.684 & 0.338 \\
\hline Wheat, unmilled & 041 & $\begin{array}{l}1.191 \\
(2.553)\end{array}$ & $\begin{array}{c}0.422 \\
(0.436)\end{array}$ & 0.500 & 2.282 & 0.503 \\
\hline Fresh Fruits & 051 & $\begin{array}{l}-0.908 \\
(-4.104)\end{array}$ & $\begin{array}{l}1.379 \\
(3.667)\end{array}$ & 0.800 & 1.327 & 0.229 \\
\hline Tea & 074 & $\begin{array}{c}0.588 \\
(0.164)\end{array}$ & $\begin{array}{c}5.935 \\
(1.325)\end{array}$ & 0.294 & 0.838 & 1.673 \\
\hline Spices & 075 & $\begin{array}{c}0.452 \\
(1.222)\end{array}$ & $\begin{array}{l}1.596 \\
(1.592)\end{array}$ & 0.644 & 2.203 & 0.379 \\
\hline Petroleum & 332 & $\begin{array}{l}0.677 \\
(0.377)\end{array}$ & $\begin{array}{l}4.507 \\
(1.854)\end{array}$ & 0.587 & 1.955 & 0.836 \\
\hline Cleansing Preparations & 554 & $\begin{array}{l}-1.576 \\
(-2.131)\end{array}$ & $\begin{array}{l}1.484 \\
(2.702)\end{array}$ & 0.417 & 1.527 & 0.332 \\
\hline \multicolumn{7}{|l|}{ Raw Materials for Consumer Goods } \\
\hline Crude Materials & 2 & $\begin{array}{c}0.508 \\
(4.090)\end{array}$ & $\begin{array}{l}1.745 \\
(6.795)\end{array}$ & 0.932 & 1.931 & 0.091 \\
\hline Waste and Used Leather & 211 & $\begin{array}{c}0.114 \\
(0.616)\end{array}$ & $\begin{array}{l}1.610 \\
(2.195)\end{array}$ & 0.392 & 1.175 & 0.238 \\
\hline Crude Rubber & 231 & $\begin{array}{c}0.351 \\
(1.168)\end{array}$ & $\begin{array}{c}0.319 \\
(0.416)\end{array}$ & 0.524 & 1.170 & 0.142 \\
\hline Wool & 262 & $\begin{array}{c}-0.489 \\
(-1.268)(\end{array}$ & $\begin{array}{l}-1.585 \\
(-1.343)\end{array}$ & 0.372 & 1.756 & 0.419 \\
\hline Worn Clothings & 267 & $\begin{array}{c}0.411 \\
(1.394)\end{array}$ & $\begin{array}{l}3.432 \\
(6.439)\end{array}$ & 0.814 & 1.652 & 0.229 \\
\hline Crude Petroleum & 331 & $\begin{array}{c}-0.200 \\
(-3.288)\end{array}$ & $\begin{array}{l}1.785 \\
(5.009)\end{array}$ & 0.712 & 2.048 & 0.091 \\
\hline Animal and Vegetable Oils & 4 & $\begin{array}{l}-0.286 \\
(-0.878)\end{array}$ & $\begin{array}{l}4.601 \\
(3.812)\end{array}$ & 0.680 & 1.900 & 0.347 \\
\hline Animal Tallow & 411 & $\begin{array}{l}-0.661 \\
(-1.969)\end{array}$ & $\begin{array}{l}2.017 \\
(3.346)\end{array}$ & 0.479 & 2.758 & 0.212 \\
\hline Soyabean Oil & 421 & $\begin{array}{l}-0.788 \\
(-2.194)\end{array}$ & $\begin{array}{l}3.591 \\
(3.360)\end{array}$ & 0.484 & 2.536 & 0.374 \\
\hline Palm Oil & 422 & $\begin{array}{l}1.682 \\
(1.426)\end{array}$ & $\begin{array}{l}9.893 \\
(2.588)\end{array}$ & 0.721 & 1.127 & 1.167 \\
\hline Chemicals & 5 & $\begin{array}{c}-0.736 \\
(-0.721)\end{array}$ & $\begin{array}{l}4.216 \\
(1.762)\end{array}$ & 0.137 & 1.495 & 0.743 \\
\hline Acids and Compounds & 512 & $\begin{array}{l}-0.131 \\
(-0.517)\end{array}$ & $\begin{array}{c}1.810 \\
(4.748)\end{array}$ & 0.676 & 1.290 & 0.161 \\
\hline Dyes and Coal Tar & 531 & $\begin{array}{l}0.891 \\
(4.306)(-1\end{array}$ & $\begin{array}{l}-5.140 \\
-10.496)\end{array}$ & 0.924 & 1.788 & 0.211 \\
\hline Urea & 561 & $\begin{array}{l}0.603 \\
(2.066)\end{array}$ & $\begin{array}{l}2.970 \\
(1.830)\end{array}$ & 0.380 & 1.179 & 0.699 \\
\hline Plastic Moulding Powder & 581 & $\begin{array}{l}-1.051 \\
(-3.265)\end{array}$ & $\begin{array}{r}3.090 \\
(3.639)\end{array}$ & 0.546 & 1.751 & 0.250 \\
\hline
\end{tabular}

where

$$
\begin{aligned}
P_{i} & =P_{i m} / P_{d i} \text { and } \\
P_{t} & =\sum_{i} P_{i}
\end{aligned}
$$

$\beta_{i}$ s are the distribution elasticities; and

$v_{t}$ is a random disturbance term.

Table 2

Distribution Elasticities

\begin{tabular}{lcc}
\hline Commodity Group & $\begin{array}{c}\text { PSTC } \\
\text { Equivalent }\end{array}$ & $\begin{array}{c}\text { Distribution } \\
\text { Elasticity }\end{array}$ \\
\hline Consumer Goods & & \\
Milk and Cream & 022 & 0.400 \\
Milk Food & 099 & 0.203 \\
Wheat, unmilled & 041 & 1.070 \\
Fresh Fruits & 051 & 1.695 \\
Tea, Black & 074 & 0.069 \\
Spices & 075 & 0.906 \\
& & \\
Raw Materials for Consumer Goods & & 1.396 \\
Waste Leather & 211 & 0.417 \\
Crude Rubber & 231 & 1.075 \\
Wool & 262 & 0.566 \\
Worn Clothing & 267 & 0.469 \\
Animal Tallow & 411 & 1.263 \\
Soyabean Oil & 421 & 1.100 \\
Palm Oil & 422 & 0.615 \\
Acids and Compounds & 512 & 1.342 \\
Dyes and Coal Tar & 531 & 2.279 \\
Urea & 561 & 1.127 \\
Plastic Moulding Powder & 581 & \\
\hline
\end{tabular}

On the basis of the distribution elasticities reported in Table 2, the derived elasticities have been obtained, using average shares of individual commodity groups 
in the total of the aggregate imports (one-digit level) for the entire period from 1969-70 to 1979-80. The directly estimated elasticities and the derived estimates are reported in Table 3.

The results in Table 3 show that the elasticities derived from disaggregated estimates diverge significantly from those obtained directly from aggregate import equations reported in Table 2. The direction of aggregation bias is upward for the price and income elasticities of Food Products ( 0 ) and for the price elasticities of Crude Materials (2) and Animal and Vegetable Oils (4). The other commodity groups show a downward bias.

Table 3

Directly Estimated and Derived Elasticities for Imports

\begin{tabular}{|c|c|c|c|c|c|c|}
\hline \multirow{2}{*}{$\begin{array}{l}\text { Commodity } \\
\text { Group }\end{array}$} & \multicolumn{2}{|c|}{$\begin{array}{c}\text { SITC } \\
\text { Equivalent }\end{array}$} & \multicolumn{2}{|c|}{$\begin{array}{c}\text { Direct } \\
\text { Estimate }\end{array}$} & \multicolumn{2}{|c|}{$\begin{array}{l}\text { Derived } \\
\text { Estimate }\end{array}$} \\
\hline & $\begin{array}{l}\text { Price } \\
\text { Elas- } \\
\text { ticity }\end{array}$ & $\begin{array}{c}\text { Income } \\
\text { Elas- } \\
\text { ticity }\end{array}$ & $\begin{array}{l}\text { Price } \\
\text { Elas- } \\
\text { ticity }\end{array}$ & $\begin{array}{c}\text { Income } \\
\text { Elas- } \\
\text { ticity }\end{array}$ & $\begin{array}{l}\text { Price } \\
\text { Elas- } \\
\text { ticity }\end{array}$ & $\begin{array}{c}\text { Income } \\
\text { Elas- } \\
\text { ticity }\end{array}$ \\
\hline $\begin{array}{l}\text { Consumer Goods } \\
\text { Food Products }\end{array}$ & 0 & 0 & 1.040 & 1.217 & 0.696 & 0.378 \\
\hline $\begin{array}{l}\text { Raw Materials } \\
\text { or Consumer Goods }\end{array}$ & & & & & & \\
\hline $\begin{array}{l}\text { Crude Materials } \\
\text { Animal \& Vegetable }\end{array}$ & 2 & 2 & 0.508 & 1.745 & 0.072 & 0.709 \\
\hline Oils & 4 & 4 & -0.286 & 4.601 & 0.279 & 6.755 \\
\hline Chemicals & 5 & 5 & -0.736 & 4.216 & 1.021 & 4.638 \\
\hline
\end{tabular}

\section{CONCLUSIONS}

On the basis of the data for the period from 1969-70 to $1979-80$ we estimate mport elasticities at a disaggregation level corresponding to the three-digit level of he PSTC for nine different sub-groups in the Consumer Goods category and thirteen lifferent sub-groups in the Raw Materials for Consumer Goods category. Price and ncome elasticities were also obtained for aggregate imports, corresponding to the ne-digit level of the PSTC.
The results showed that relative price, adjusted for customs duties and an income variable, were enough to explain a large proportion of the variation in the imports of individual commodity groups as well as in aggregate imports. For several sub-groups the price elasticities were significant and had the expected signs. The income elasticities are on the higher side. There were some cases in which the relative-price variable turned out to be statistically insignificant. In a few other instances the relative-price variable was significant but positive. In these cases there is a need to specify additional factors which can influence import demand.

The derived estimates of import elasticities were lower than those obtained directly from the equations estimated for aggregate imports, corresponding to the one-digit level of SITC, implying a downward aggregation bias. The important exceptions were the price and income elasticities for the imports of Animal and Vegetable Oils and Chemicals, which were biased upward.

\section{REFERENCES}

1. Khan, M. S. "The Structure and Behaviour of Imports of Venezuela". Review of Economics and Statistics. Vol. LXII, No. 2. 1975.

2. Kreinin, M. "Disaggregate Import Demand Functions - Further results". Southern Economic Journal. Vol. 40, No. 1. 1973.

3. Mahmood, Riaz. Growth and Structure of Imports of Pakistan (1959-60 to 1978-79). Islamabad: Pakistan Institute of Development Economics. 1980. (Statistical Paper Series No. 3).

4. Melo, O., and Michael G. Vogt. "Determinants of the Demand for Imports of Venezuela”. Journal of Development Economics. Vol. 14, No. 3. 1984.

5. Nguyen, D. T., and A. R. Bhuyan. "Elasticities of Export and Import Demand in Some South Asian Countries. Some Estimates". Bangladesh Development Studies. Vol. V, No. 2. 1977.

6. Pakistan. Central Statistical Office. Foreign Trade Statistics of Pakistan. Karachi. (Various Issues)

7. Pakistan. Central Statistical Office. Pakistan Standard Trade Classification. Revision 1,(PSTC). Karachi. July 1966.

8. Pakistan. Finance Division. Economic Adviser's Wing. Pakistan: Basic Facts Islamabad. (Various Issues)

9. Pakistan. Finance Division. Economic Adivser's Wing. Pakistan Economic Survey. Islamabad. (Various Issues)

10. Pakistan. Ministry of Food, Agriculture and Cooperatives. Food and Agriculture Division (Planning Unit). Agricultural Statistics of Pakistan. Islamabad (Various Issues) 
11. Pakistan. Statistics Division. Pakistan Statistical Yearbook Karachi. (Various Issues)

12. Price, J. E., and J. B. Thornblade. "U.S. Import Demand Functions Disaggregated by Country and Commodity". Southern Economic Journal. Vol. 39, No.1.1972.

\section{Comments on \\ "Price and Income Elasticities of Consumer Goods Imports of Pakistan"1}

I share the authors' assertion that disaggregated import demand functions are hard to come by for the Third World countries. They should be commended for their efforts to fill this void. My comments are intended to raise a few conceptual points and should not be construed as a criticism of the authors' professional competence.

\section{Data}

Use of Pakistan's trade data on functional classification on commodities into consumption goods and raw materials for consumption goods begs for a reconciliation with a classification of commodities based on the economic characteristics of a commodity. The apparent arbitrariness in Pakistan's trade data is best removed in an input-output framework where a clear distinction between intermediate use and final demand use of commodities is maintained. I assume that the authors had an access to PIDE's input-output tables for 1975-76. I wonder why they did not modify the functional classification of commodities into meaningful categories based on the economic characteristics.

A related point is that of the use of prices of domestic substitutes. What if there is no imaginable domestic substitute available? What kind of prices would one use? Palm oil or crude rubber are good examples of this issue. It may be that an industry in question needs these items which are imported, and without whose availability their outputs cannot be produced. It would be, in my opinion, desirable to distinguish between competitive and non-competitive imports.

\section{Model Specification}

My comments refer to the choice of real income as an explanatory variable. A correction is required in the explanation of the symbol $y_{t}$ : real consumption expenditure for consumer goods should be read as real private consumption expenditure, as it is clearly stated in the assumptions listed by the authors.

${ }^{1}$ Comments by the discussant are based on the paper distributed and presented in the meeting and not on the revised version of the paper. (Editor) 
Firstly, there are problems in using Pakistan's National Accounts data on total consumption expenditure. These aggregate data in the Accounts are obtained residually. Then, I assume, some other ad hoc basis is used to disaggregate it further into private and government consumption expenditure.

Secondly, the choice of deflators to transform the current-prices data into constant prices needs to be carefully examined. It is not made explicit in the paper what the base-year is of the prices that have been used to transform the data. If I recall the PIDE's Macroeconometric Model, 1959-60 was the base year. I noticed from the Model's series of private consumption that there were two or three years when the observed consumption expenditure exceeded the observed income. The unreliable nature of data on this variable is clearly evident.

Thirdly, I would like to know the deflators used for determining real value added in manufacturing. How does one deflate various components of the value added such as wages, salaries and profits? Is it fair to assume that 100 percent of the profit income earned by industries is spent? It must be remembered that profits are not the only component of the value added.

Suppose the choice of real private consumption expenditure as a proxy for real income is a good one. This appears as an explanatory variable in the equation. How can one digest the fact that while consumption is usually a function of income it has been used here as a dependent variable which is a function of itself. It is then used to explain the behaviour of another dependent variable - in this case, demand for an imported commodity.

\section{Interpretation of Results}

Invariably, the estimated price and income elasticities have been compared with the results obtained from other studies - e.g., the one by Khan for Venezuela. In the absence of any description of these other studies with respect to the choice of variable, estimation methods used, size of the sample period, functional forms, etc., it is rather arbitrary to draw any comparative inferences.

In my opinion, such a comparison is unwarranted: for, as the authors claim, many of these other studies are not as disaggregated as their own. The authors further claim that increase in the magnitude of income elasticities over time increases the degree of "openness" of an economy. I do not quite understand this point. Does it relate to import liberalization as a function of rising income levels or what? Do the facts surrounding import policy as an allocative instrument of resources in Pakistan justify this prescription.

Senior Analyst

Dr Aftab A. Syed

Input-Output Division,

Statistics Canada,

Ottawa (Canada) 